\title{
Recorregut de recerca geològica i mineralògica per la subcomarca del Lluçanès (comarca d'Osona): des de Lluçà a Santa Eulàlia de Puig- Oriol, Sant Agustí de Lluçanès i Alpens
}

Josep Maria Mata-Perelló

Joaquim Sanz Balagué

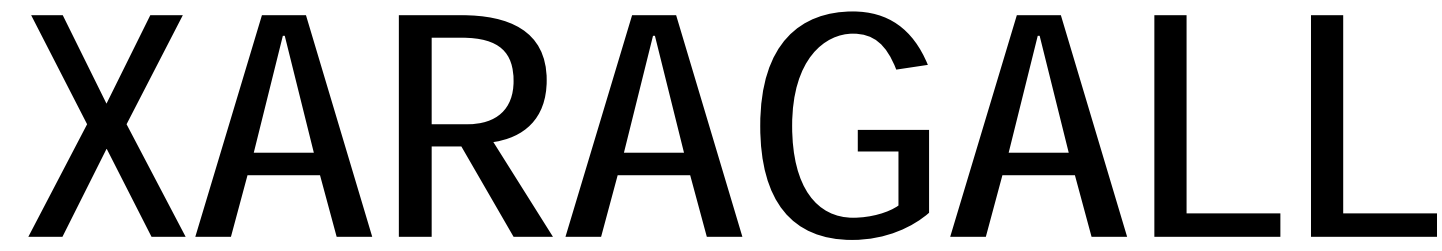

REVISTA DE CIÈNCIES DE LA CATALUNYA CENTRAL

n. 4

ABRIL 2014 


\title{
RECORREGUT DE RECERCA GEOLÒGICA I MINERALÒGICA PER LA SUBCOMARCA DEL LLUÇANÈS (COMARCA D'OSONA): DES DE LLUÇÀ A SANTA EULÀLIA DE PUIG-ORIOL, SANT AGUSTÍ DE LLUÇANÈS I ALPENS
}

\author{
Josep Maria Mata-Perelló \\ Museu de geologia Valentí Masachs, Escola Politècnica Superior d'Enginyeria de Manresa \\ (EPSEM), Universitat Politècnica de Catalunya · BarcelonaTech (UPC), 08272 Manresa, Spain
}

\section{Joaquim Sanz Balagué}

Departament d'Enginyeria Minera i Recursos Naturals (EMRN), Escola Politècnica Superior d'Enginyeria de Manresa (EPSEM), Universitat Politècnica de Catalunya - BarcelonaTech (UPC), 08272 Manresa, Spain

Paraules clau: Cenozoic; Depressió geològica de l'Ebre; relleus en costa; Patrimoni miner

\section{Resum}

Itinerari realitzat el 14 d'abril del 2013. En aquesta ocasió el recorregut de d'itinerari discorrerà en la seva totalitat per la Depressió Geològica de l'Ebre (i més concretament, ho farà pel seu sector corresponent a la seva Depressió Central).

Tot i així, l'itinerari passarà per les proximitats d'alguns indrets més o menys replegats de I'esmentada depressió. Així, entre altres, creuarem el Sinclinal de Gironella i I'Anticlinal de Puig-reig, entre altres elements.

Així, des del seu inici a la localitat osonenca i lluçanenca alhora de Lluçà, fins a la seva fi, pels voltants de la localitat d'Alpens, igualment situada a la subcomarca del Lluçanès (comarca d'Osona), totes les aturades del recorregut de l'itinerari es trobaran ubicades dintre d'aquesta unitat geològica anteriorment esmentada.

Per d'altra banda, i com ja s'entreveu al títol, el recorregut de l'itinerari discorrerà íntegrament per la subcomarca del Lluçanès i més concretament pels seus sectors osonencs, des de principi a fi del recorregut. 


\section{Objectius fonamentals}

Els objectius que s'esperen aconseguir en el transcurs d'aquest itinerari es centraran, fonamentalment, en els següents aspectes:

1. S'observarà l'estructura de la Depressió Geològica de l'Ebre (i més concretament del seu sector de la Depressió Central), per la qual circularà quasi al llarg de tot el recorregut de l'itinerari, entre Lluçà i Alpens. Així, s'intentaran observar les diferents estructures representades en el recorregut, com les següents: el Sinclinal de Gironella, I’Anticlinal de Puig-reig, entre altres elements estructurals.

2. S'observarà molt puntualment l'estructura de la Depressió Geològica de l'Ebre (al seus sectors més septentrionals de l'Avant-país Plegat), que veurem pels voltants de la població d'Alpens, cap a la fi del recorregut.

3. Es reconeixeran els materials cenozoics que constitueixen el rebliment de la Depressió Central. per aquests indrets. Aquests materials, eminentment oligocènics (i eocènics), es reparteixen dintre del recorregut de d'itinerari, entre els afloraments que pertanyen a les següents unitats biostratigràfiques: Complex Al-luvial de Berga i Formació Solsona.

4. Observació, per arreu de diferents exemples de relleus en costa, i de la seva disposició en funció de l'estructura de la zona, per la qual discorre aquest itinerari.

5. Observació al llarg de tot el recorregut, de tots els elements relacionats amb el Patrimoni Geològic i Miner, de la subcomarca del Lluçanès.

\section{Antecedents}

No coneixem cap antecedent relatiu al conjunt d'aquest itinerari. Hi ha un sol antecedent parcial nostre, relatiu als trams inicials del recorregut de l'itinerari. Es tracta de Mata-Perelló (2013). Tret d'aquest, no en coneixem cap altre que discorri per aquests indrets. Així, es pot considerar a l'actual itinerari com una primícia.

Com antecedents geològics de caire general, corresponents als trets geològics bàsics catalans, considerarem els treballs de: Guimerà et altri (1992), així com el de Riba et altri (1976), referits al conjunt dels Països Catalans. Tanmateix farem esment del treball corresponent a l'IGME (1975). Dintre dels caràcters mineralògics dels indicis per on discorrerà d'itinerari, farem esment d'un antecedent mineralògic general: Mata-Perelló (1991), referit al conjunt de Catalunya.

Tots aquests treballs, i d'altres, es trobaran relacionats a l'apartat dedicat a les referències bibliogràfiques, al qual ens remetem.

\section{Recorregut de d'itinerari}

L'iniciï del recorregut de d'itinerari, es realitzarà per les immediacions de la població de Lluçà, per on es farà la primera aturades. Després, el recorregut es dirigirà cap a la localitat de Santa Eulàlia de Puig - Oriol, per on es faran diverses aturades. Després, el recorregut es dirigirà cap a les immediacions de Sant Agustí de Lluçanès. 
En arribar a la darrera població esmentada (al nucli principal de Sant Agustí de Lluçanès) es realitzaran diverses aturades. Finalment, el recorregut de l'itinerari s'encaminarà cap a la població d'Alpens, per on finalitzarà aquest trajecte, després de fer les darreres aturades del recorregut.

En aquest recorregut, haurem circulat inicialment per la carretera local BV - 4341, entre Lluçà, Santa Eulàlia de Riuprimer, fins a trobar (prop de la tercera població esmentada, Sant Agustí de Lluçanès) la carretera BV - 4653. Posteriorment, quasi en arribar a Sant Agustí, trobarem la carretera local BV - 4654, per la que circularem fins a la fi del recorregut.

\section{Advertiment previ}

Com en altres recorreguts de recerca geològica i mineralògica ..., si es disposa del temps suficient, poden efectuar-se passant per totes les parades i filloles. En cas contrari, recomanem prescindir de les anomenades parades - condicionals.

Com en altres recorreguts, recomanem demanar informació sobre l'estat dels camins, abans d'iniciar d'itinerari. En especial pels indrets on s'han d'efectuar trajectes per camins de terra. En aquest itinerari n'hi ha molt pocs. Un d'ells és l'accés a les immediacions del Castell de Lluçà i a l'ermita de Sant Vicenç de Lluçà.

Per d'altra banda, i en qualsevol cas, cal tenir sempre una cura molt especial de respecte a la natura, al llarg de tot el recorregut de d'itinerari.

\section{Descripció de l'itinerari}

Com ja es habitual, s'estructurarà en una sèrie d'estacions (parades o aturades), en les qual es faran descripcions geològiques o mineralògiques, si s'escau. En cada cas s'indicarà el número del mapa topogràfic a escala 1:50.000 on es troba l'indret.

En aquest cas, el recorregut de l'itinerari passarà pels fulls següents: 293 (o de Berga) i 294 (full de Manlleu), de I'Instituto Geográfico y Catastral" espanyol, a escala 1:50.000.

Així doncs, la relació i descripció de les aturades que composen aquest itinerari, és la següent:

\subsection{Parada 1 - Condicional. Carretera local BV-4341, d'accés a Lluçà, (terme municipal de Lluçà, comarca d'Osona, subcomarca del Lluçanès). (Full 293).}

El recorregut de l'itinerari el començarem dintre del municipi de Lluçà; concretament a la cruïlla de la carretera autonòmica catalana C - 62 (de Gironella a Vic, antiga carretera comarcal C154) amb la carretera local BV-4341, la qual es dirigeix cap als pobles de Lluçà i Santa Eulàlia de Puig - Oriol. A poc més de $1 \mathrm{Km}$ de l'inici del recorregut, farem la primera aturada, per les immediacions de la Costa Alta.

Aquest recorregut l'hem efectuat íntegrament entre els afloraments dels materials cenozoics que reblen la Depressió Geològica de I'Ebre (o Conca de l'Ebre), per on ara ens trobem i per on es farà la totalitat del recorregut de l'itinerari. Així, haurem trobat afloraments dels terrenys detrítics del Complex Al-luvial de Berga (amb nivells de conglomerats i gresos de tonalitats ocres), tot i que ben prop de l'inici del recorregut apareixen els terrenys de la Formació Solsona 
(amb nivells de gresos i calcolutites de tonalitats també ocres). Aquests materials són d’origen continental.

Sovint, entre aquests materials es fa palesa la presencia de paleocanals, com el que es pot observar a l'indret de la present aturada.

\subsection{Parada 2. Cim del Castell de Lluçà, (terme municipal de Lluçà, comarca d'Osona, subcomarca del Lluçanès). (Full 293).}

Després de realitzar l'aturada anterior, cal seguir cap al NE, per tal d'anar cap el poblet de Lluçà, seguint sempre per la carretera local BV - 4341. En arribar-hi, caldrà seguir poc més de $1 \mathrm{Km}$, fins a trobar el trencall (per l'esquerra) d'on surt el camí que es dirigeix cap el Castell. Tot i així, en arribar al Mas de Can Roviralta, haurem de deixar el cotxe per a continuar a peu fins al cim on hi ha el Castell. En arribar-hi, farem una nova aturada, a uns $4 \mathrm{Km}$ des de la parada anterior.

En aquest recorregut, hem tornat a trobar afloraments dels materials detrítics del Complex Al. luvial de Berga. Aquests son els materials que apareixen a l'indret de la present aturada, on afloren aquests nivells de conglomerats i gresos, de tonalitats generalitzades de colors ocres.

També cal dir que a la base del turó, es fa ben palès l'aflorament d'uns nivells eminentment calcolutitics, de tonalitats ocres (lleugerament rogenques) força argilosos, que es troben a tocar del Mas de Can Roviralta.

Des d'aquest indret força enlairat, es pot gaudir d'una bona visió de la subcomarca del Lluçanès, especialment pels voltants de Lluçà i de Prats de Lluçanès. Així, es poden veure molt clars els relleus tabulars que sovint caracteritzen aquests indrets de la Depressió Geològica de I'Ebre, on estem ara situats. (fotografia 1).

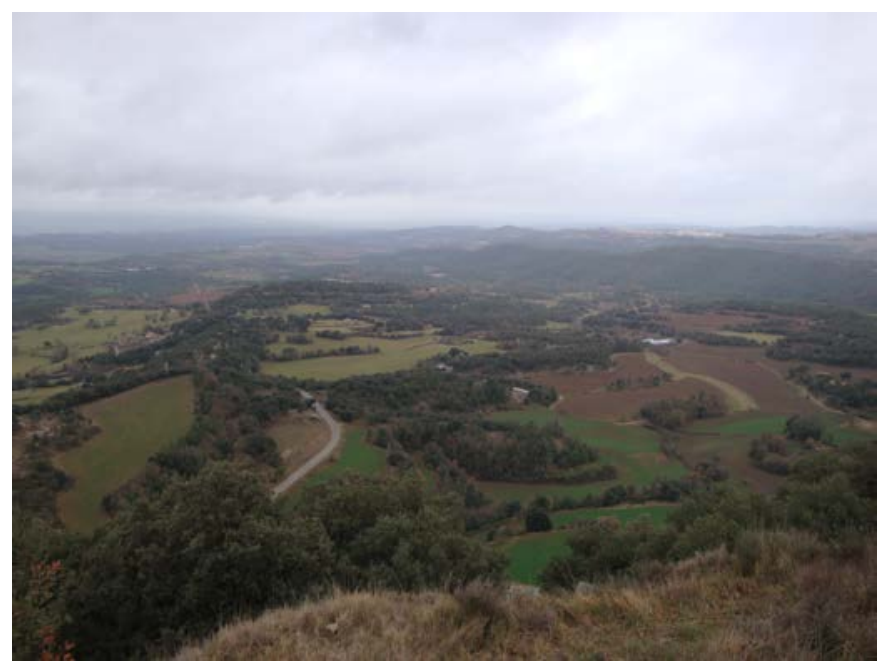

Fotografia 1. Voltants del Lluçanès, des del Castell de Lluçà

També cal dir que per les immediacions del Castell, per on hem fet aquesta primera aturada, es troba la interessant església de Sant Vicenç de Lluçà, un excel-lent exemple del romànic del Lluçanès. Es una església de base semicircular que val la pena veure en aquest itinerari geològic. Precisament, I'haurem trobat quasi en arribar dalt del Castell. 


\subsection{Parada 3 - condicional. Carretera BV-4341, immediacions del km 12, (terme municipal de Lluçà, comarca d'Osona, subcomarca del Lluçanès). (Full 293).}

Després de realitzar l'aturada anterior, cal retornar a la carretera local BV - 4341, amb la finalitat de continuar, ara cap a I'Est. En arribar a les immediacions del Km 12 de la carretera, per les proximitats de Casanova del Castell. Així, des de la parada anterior, haurem recorregut poc més d'uns $4 \mathrm{Km}$.

En aquest recorregut, hem continuat trobant afloraments dels materials esmentats anteriorment, els quals pertanyen al Complex Al-luvial de Berga. Així, haurem vist afloraments de gresos i de conglomerats, fonamentalment.

En aquest indret, es fa clarament palès un nivell de conglomerats, una barra detrítica, que destaca enormement en el paisatge. Aquesta barra correspon a un paleocanal, desenvolupat entre els materials oligocens anteriorment esmentats. (fotografia 2).

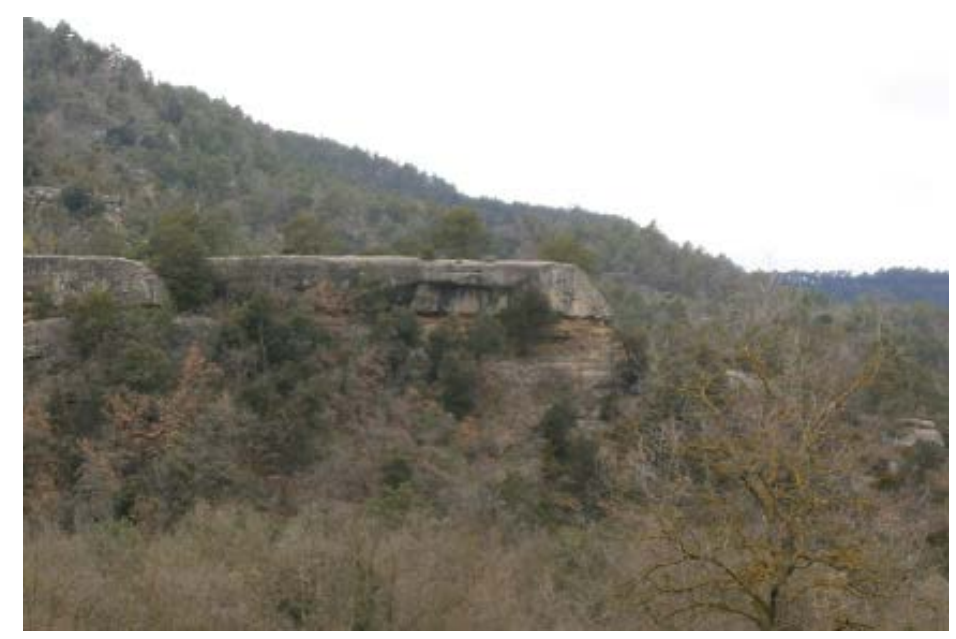

Fotografia 2. Aflorament d’una barra detrítica, prop de Casanova del Castell

\subsection{Parada 4 - condicional. La gola de la riera Lluçanès, (Santa Eulàlia de Puig - Oriol, terme municipal de Lluçà, comarca d'Osona, subcomarca del Lluçanès). (Full 293).}

Després de realitzar l'aturada anterior, cal seguir cap a llevant, per la carretera local BV - 4341, apropant-nos cada vagada més cap al poble de Santa Eulàlia de Puig - Oriol, la capçalera del municipi de Lluçà. En arribar al trencall que es dirigeix cap a Can Rocadenbosc, (per l'esquerra de la carretera) ens caldera agafar-lo. Poc després, trobarem (per la dreta) un trencall que es dirigeix cap el Nord, dirigint-se cap a l'embassament de Santa Eulàlia. Ens caldrà agafar-lo. Així, arribarem a l'esmentat embassament. Molt prop d'ell, es troba la gola del riu Lluçanès, per on farem la present aturada. Així, des de l'anterior, haurem efectuat un recorregut proper als 3’5 Km.

En aquest recorregut, hem anat trobant afloraments dels materials esmentats a les aturades anteriors. Aquests materials pertanyen al Complex Al-luvial de Berga, fonamentalment de I'Oligocè Inferior. Aquests són els materials que apareixen per l'indret de la present aturada. 
Així, haurem vist afloraments de nivells de gresos i de conglomerats de tonalitats eminentment ocres.

Aquests són els materials que apareixen per les immediacions de l'indret de la present aturada. Aquí, la Riera Lluçanès (tributària de la Riera Gabarresa) presenta un engorjament al travessar els materials detrítics acabats d'esmentar. (fotografia 3).

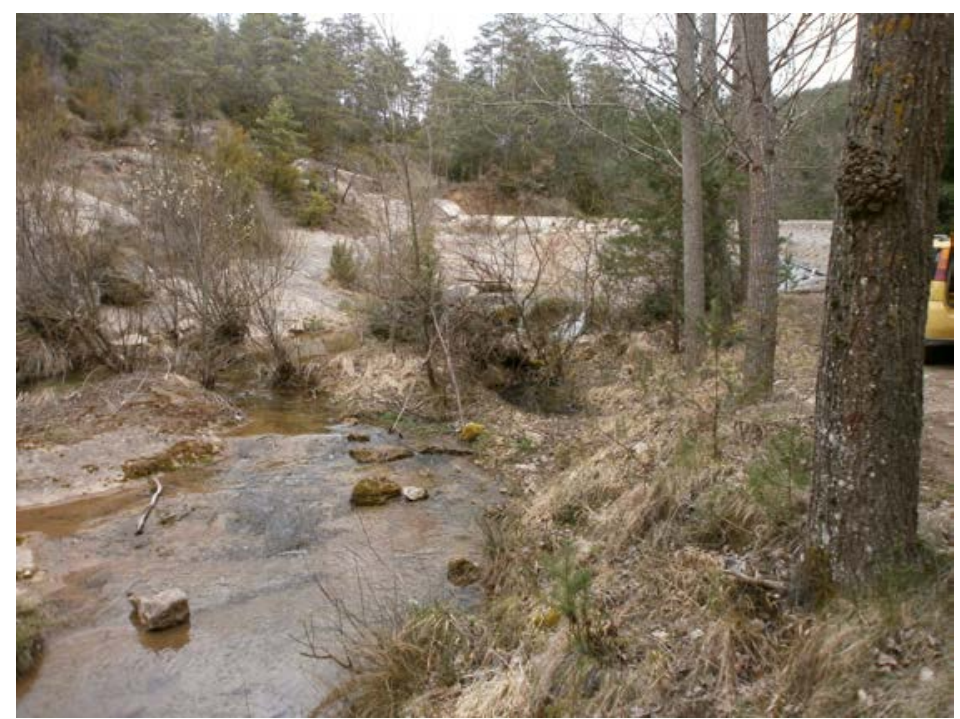

Fotografia 3. Immediacions de la gola del Lluçanès, prop de Santa Eulàlia de Puig-Oriol

\subsection{Parada 5 - condicional. Carretera BV-4341, immediacions del Km 8, (Santa Eulàlia de Puig - Oriol, terme municipal de Lluçà, comarca d'Osona, subcomarca del Lluçanès). (Full 293).}

Després de realitzar l'aturada anterior, cal retornar cap a la carretera BV - 4341, per tal de seguir cap a llevant. Així, aviat arribarem al poblet de Santa Eulàlia de Puig - Oriol , la capçalera del municipi de Lluçà. Després, ens caldrà continuar per la mateixa carretera, anant ara cap Sant Agustí de Lluçanès. En arribar a les immediacions del Km 8, si s'escau, farem una nova aturada. Així, des de la parada anterior, haurem efectuat un recorregut proper als 4’5 $\mathrm{Km}$ des de la parada anterior.

En aquest recorregut, hem trobat afloraments dels nivells de gresos i de calcolutites (margues) de tonalitats ocres. Aquests materials pertanyen a l'Eocè Superior, concretament al Priabonià. Aquests són també els materials que apareixen pels voltants de l'indret de la present aturada, on ara som.

Des d'aquest lloc, mirant cap a l'Est es pot gaudir d'una bona visió de la Riera de la Gabarresa. Aquesta riera constitueix el principal medi d'escorrentia del conjunt de la subcomarca del Lluçanès. Així, des d'aquest indret es pot veure la vall d'aquest curs d'aigua. (fotografia 4). 


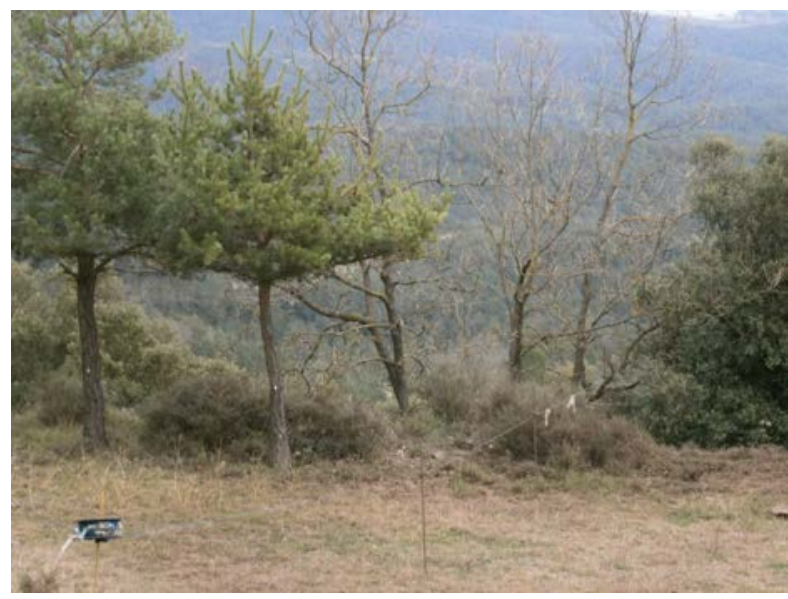

Fotografia 4. La Vall de la Riera Gabarresa, prop de Santa Eulàlia de Puig - Oriol

\subsection{Parada 6. Immediacions de Sant Cristòfol de Borrasers, (Santa Eulàlia de Puig - Oriol, terme municipal de Lluçà, comarca d'Osona, subcomarca del Lluçanès). (Full 293).}

Després de realitzar l'aturada anterior, cal seguir per la carretera local BV - 4341, anant sempre cap a l'Est (de vegades cap a l'ENE). En arribar a les immediacions del Km 7, ens caldrà agafar, per l'esquerra de la carretera, el trencall que es dirigeix cap a l'ermita de sant Cristòfol de Borrasers i cap Alpens. En arribar prop de l'ermita, farem una nova aturada després de recórrer uns $2 \mathrm{Km}$ des de la parada anteriorment feta.

En aquest recorregut, hem trobat afloraments dels materials cenozoics de l'Eocè Superior, els quals pertanyen al Priabonià. Així, haurem vist afloraments de gresos i calcolutites de tonalitats eminentment ocres.

Aquests materials són els que apareixen a l'indret de la present aturada, prop de l'ermita de Sant Cristòfol. Sovint, entre aquests materials es fa ben palesa la presencia de paleocanals, com el que apareix molt prop de l'ermita (FOTOGRAFIA 5). Aquests paleocanals es troben constituïts per trams eminentment detrítics, amb gresos i amb conglomerats.

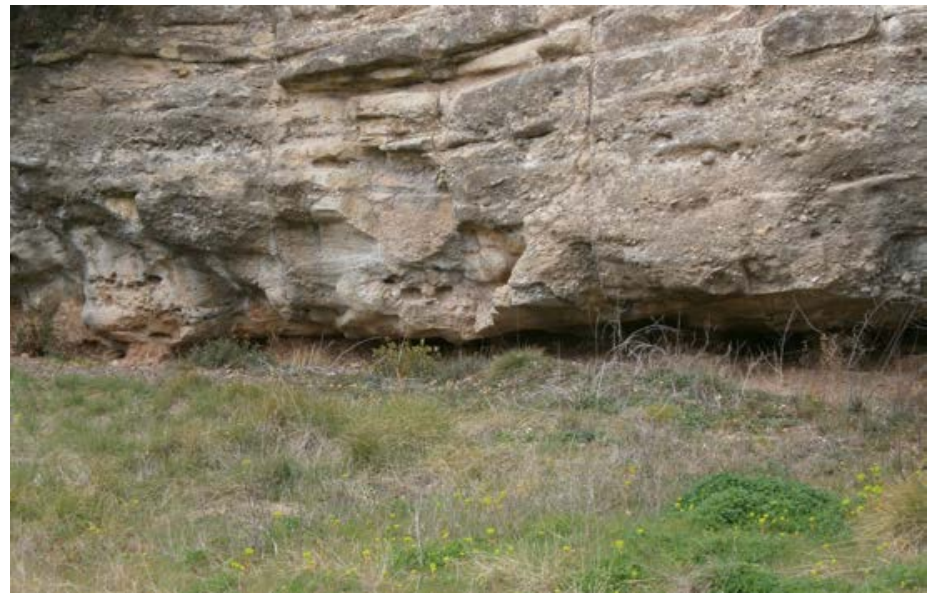

Fotografia 5. Paleocanal de les immediacions de Sant Cristòfol de Borrasers 
Per d'altra banda, des d'aquest indret (mirant cap el Sud) es pot gaudir d'un bon lloc d'observació d'amplis sectors de la subcomarca del Lluçanès.

\subsection{Parada 7. Mare de Déu dels Munts, (terme municipal de Sant Agustí de Lluçanès, comarca d'Osona, subcomarca del Lluçanès). (Full 294).}

Després de realitzar l'aturada anterior, cal retornar a la carretera local BV - 4341, amb la idea de continuar per ella cap a llevant. Més endavant, després de sobrepassar la Riera Gavarresa, arribarem a la cruilla amb la carretera local BV - 4653 (procedent de Perafita). En trobar-la, ens caldrà seguir per ella, tot anant ara cap el Nord, cap a Sant Agustí de Lluçanès. Més endavant, deixarem a la dreta el trencall de la carretera local que es dirigeix cap a Sant Boi de Lluçanès. En tot cas, ens caldrà seguir cap al Nord. Ben aviat, trobarem per la dreta, el trencall que es dirigeix cap al Santuari de la Mare de Deu dels Munts, cap on ens caldrà anar. En arribar-hi, farem una nova aturada, després de recórrer uns $8 \mathrm{Km}$ des de la parada anteriorment realitzada.

En aquest recorregut, hem continuat trobant afloraments dels materials cenozoics esmentats a les aturades anteriors. Cap a les immediacions del Santuari, hem trobat afloraments d'uns nivells de gresos (sovint conglomerats) i calcolutites, que pertanyen a l'Eocè, concretament al Bartonià. Aquests materials formen part de l'extrem occidental de l'Anticlinal de Bellmunt.

Aquest indret, força enlairat, ens permet fer una bona observació dels relleus situats entorn d'on ara som. Així, mirant cap a llevant es poden veure els relleus del Vidranès, de Bellmunt i del Cabrerès, amb el Coll sa Cabra. (fotografia 6).

Mirant cap el Nord, es poden veure els relleus de la Corbatera, Sant Quirze de Besora i Montesquiu; així com de bona part del conjunt del Bisaura, al Nord de la comarca d'Osona. (fotografia 7).

Tanmateix, mirant cap el Sud, es poden veure els relleus en costa dels voltants de Sant Boi de Lluçanès i la Trona (fotografia 8). Així, aquest indret constitueix un bon lloc d'observació de tots els voltants.

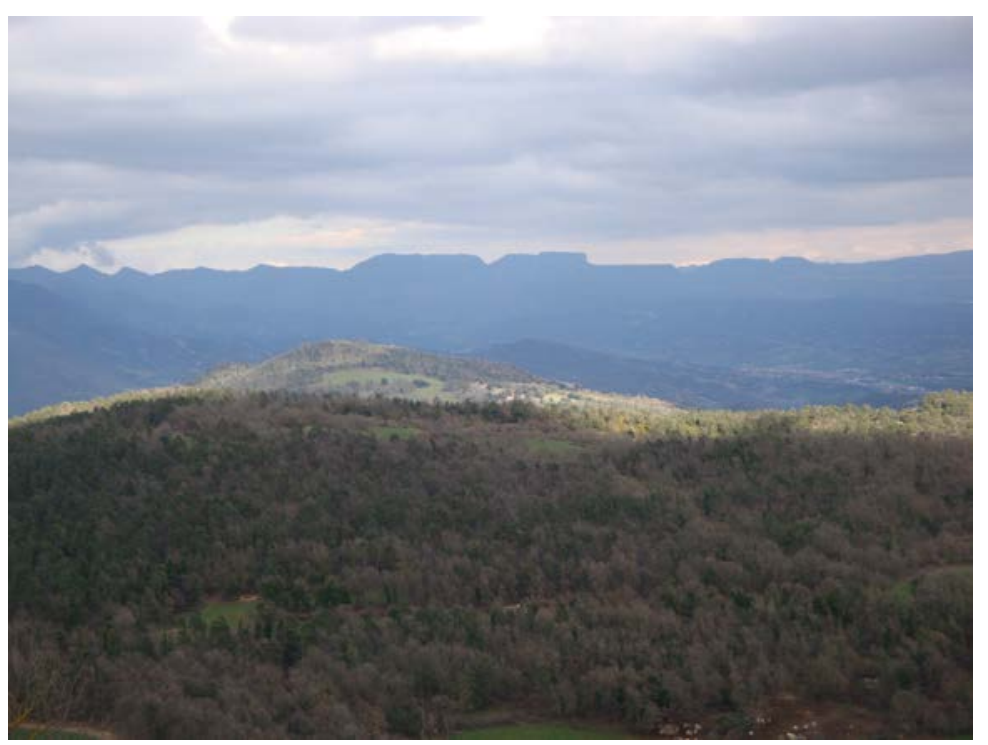

Fotografia 6. Relleus del Vidranès, de Bellmunt i del Cabrerès, des de la Mare de Deu dels munts

Xaragall.2014 n. 4 | Recorregut de recerca geològica i i mineralògica per la subcomarca del Lluçanès (comarca d'Osona): des de Lluçà a Santa Eulàlia de Puig-Oriol, Sant Agustí de Lluçanès i Alpens 


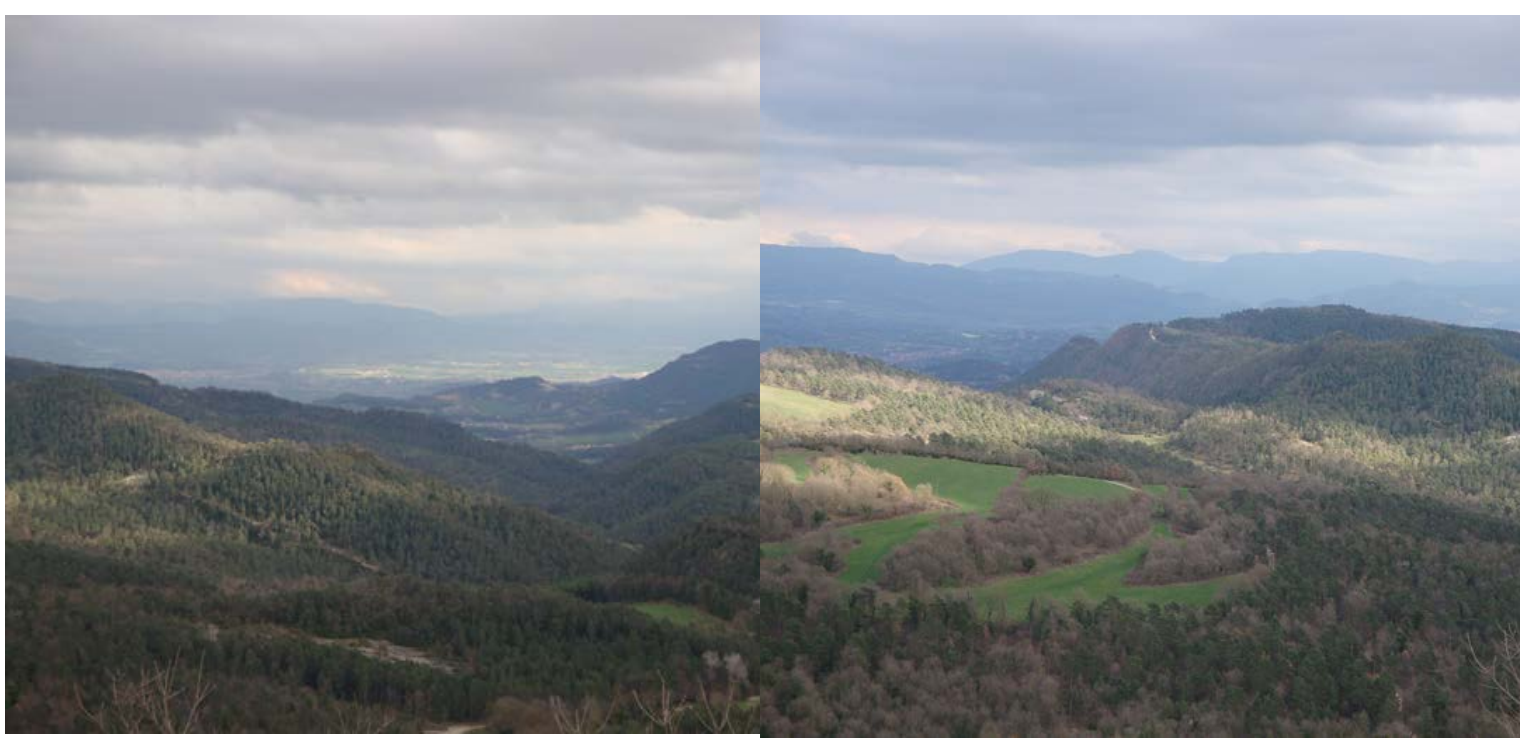

Fotografia 7. Relleus dels voltants de la Corbatera, Montesquiu i la Bisaura, des de la Mare de Déu dels Fotografia 8. Relleus de Sant Boi de Lluçanès i de la Munts Trona, des de la Mare de Déu dels Munts

\subsection{Parada 8 - Condicional. Collet de Sant Agustí, cruïlla de les Carreteres BV- 4654 i BV-4653, (terme municipal de Sant Agustí de Lluçanès, comarca d'Osona, subcomarca del Lluçanès). (Full 293).}

Després de realitzar I'aturada anterior, cal retornar cap a la carretera BV - 4653 (procedent de Perafita). Per aquesta carretera arribarem al Collet de Sant Agustí, on hi ha la cruilla amb la carretera BV - 4654. En aquest indret, si s'escau, podem fer una nova aturada, a uns $6 \mathrm{Km}$ de I'anterior.

En aquest recorregut, hem anat trobant els materials eocens del Bartonià, que ja hem vist a l'aturada anterior. Així haurem trobat nivells de gresos (de vegades conglomeràtics) i de calcolutites.

En aquest indret, estem al flanc septentrional de I'Anticlinal de Bellmunt, el qual presenta una direcció pràcticament d’Est a Oest. Així, nosaltres ara ens trobem als sectors més occidentals d'aquesta alineació.

\subsection{Parada 9 - condicional. Carretera BV-4654, immediacions del Km 116, (terme municipal de Sant Agustí de Lluçanès, comarca d'Osona, subcomarca del Lluçanès). (Full 293).}

Després de realitzar l'aturada anterior, cal seguir cap al Nord, per tal d'anar cap el proper poble de Sant Agustí de Lluçanès, seguint sempre per la carretera local BV - 4654, que hem agafat a la parada anterior (aquesta carretera procedeix de Sant Quirze Safaja). Així, després de sobrepassar el primer poble esmentat, en arribar a les immediacions del $\mathrm{Km} \mathrm{11} 6$, farem una nova aturada. Així, des de l'anterior, haurem recorregut uns $3 \mathrm{Km}$ més, per tal d'arribar fins aquí. 
En aquest recorregut, haurem trobat afloraments dels materials eocènics, primer del Bartonià i després del Priabonià. Aquests darrers, de I'Eocè Superior, són els que es troben a l'indret de la present aturada. Així, haurem trobat afloraments de gresos i de calcolutites de tonalitats ocres.

En aquest indret es fa palesa una important barra de materials detrítics. Es tracta d'un aflorament de gresos i de conglomerats, intercalada entre nivells de calcolutites de tonalitats eminentment ocres. Aquesta "barra" es fa força palesa a l'indret de la present aturada. (fotografia 9).

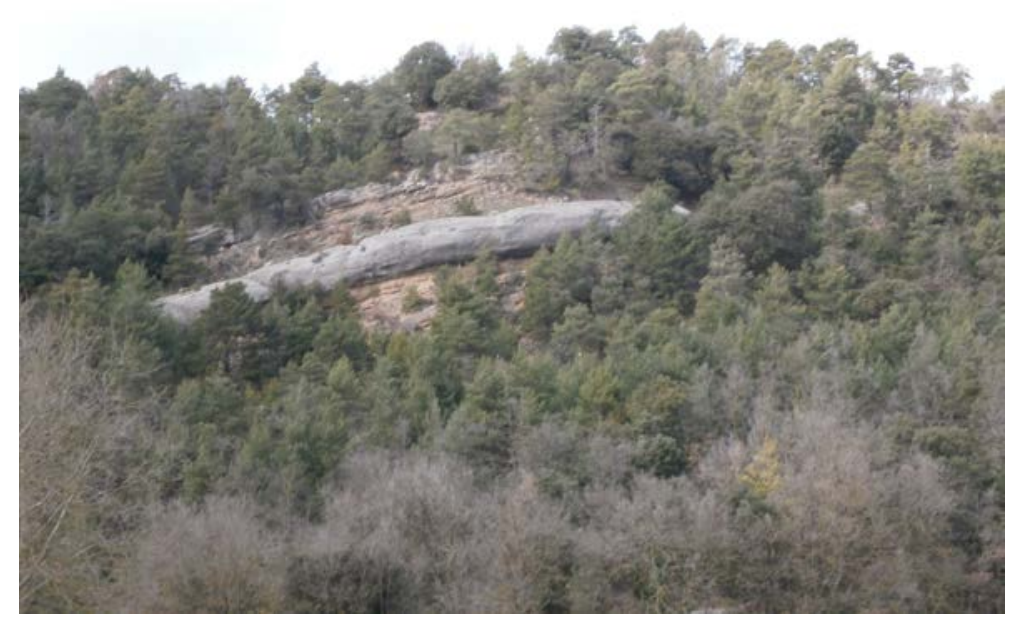

Fotografia 9. Barra de gresos i conglomerat, intercalada entre nivells de calcolutites ocres del Priabonià

\subsection{Parada 10 - condicional. Carretera BV-4654, immediacions del Km15'7, (terme municipal d'Alpens, comarca d'Osona, subcomarca del Lluçanès). (Full 293).}

Després de realitzar l'aturada anterior, cal continuar el recorregut cap el Nord, seguint sempre la carretera local BV - 4654, la qual es dirigeix ara cap el proper poble d'Alpens. En arribar a

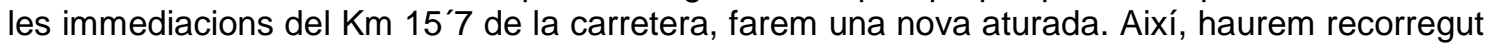
uns $4 \mathrm{Km}$ més i ens trobarem molt prop de l'entrada de la carretera a la població d'Alpens (a uns $2 \mathrm{Km}$, aproximadament).

En aquest recorregut, hem anat trobant afloraments dels materials de I'Eocè Superior, que corresponen al Priabonià. Aquests materials son els que apareixen a l'indret de l'aturada. Així, ara veiem afloraments de gresos i de calcolutites de tonalitats eminentment groguenques (generalment brunes). Aquests materials reblen la Depressió Geològica de l'Ebre, on ara estem situats, des del principi del recorregut de l'itinerari.

Aquests materials es troben força replegats. Efectivament, formen part de I'anomenat Avant País Plegat, on ara estem situats, en aquest sector de la depressió esmentada a l'apartat anterior. Així, hi ha un conjunt d'estructures de direcció quasi generalitzada $\mathrm{E}-\mathrm{W}$, que ha produït el plegament d'aquests materials. Tot això es fa força palès pels voltants de la població d'Alpens, especialment al nord de la mateixa. 
Des d'aquest lloc, mirant cap a l'Est, es pot gaudir d'una bona missió dels relleus de la Vall del rec de Matamasses i tanmateix de la Serra de Novelles. Tot això es fa força palès des de I'indret on ara ens trobem. FOTOGRAFIA 10.

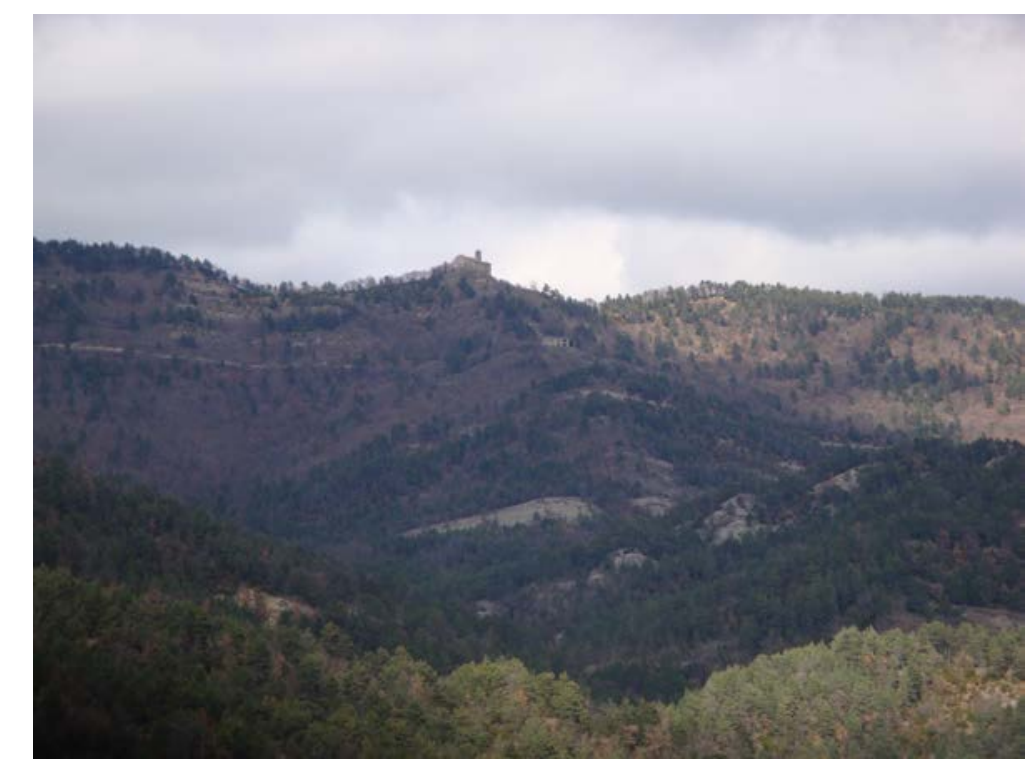

Fotografia 10. Un aspecte de la Serra de Novelles, del terme de les Lloses (Ripollès)

\subsection{Parada 11. Roca de Pena, (terme municipal d'Alpens, comarca d'Osona, subcomarca del Lluçanès). (Full 293).}

Després de realitzar l'aturada anterior, cal seguir cap al Nord, amb la intenció d'entrar i sobrepassar el poble d'Alpens. Posteriorment, seguirem encara $1 \mathrm{Km}$ més per la carretera local BV - 4654. Més endavant, trobarem per la dreta un camí - carreter, que es dirigeix cap els Torrats i cap a la Roca de Pena. En arribar a aquest darrer indret, farem una nova aturada, a uns $2 \mathrm{Km}$ d'Alpens i a uns $4 \mathrm{Km}$ des de la parada anterior. Així, quasi haurem arribat al límit del terme municipal d’Alpens, tocant al de les Lloses (de la comarca del Ripollès).

En aquest recorregut. Hem anat trobant afloraments dels materials esmentats a l'aturada anterior. Així, haurem trobat afloraments dels nivells de gresos i de calcolutites ocres del Priabonià Superior. Molt sovint els gresos són força conglomeràtics.

En aquest indret hi ha un potent nivell dels gresos i conglomerats del Complex Al-luvial de Berga. Aquests materials els hem trobat quasi a l'indret de la present aturada. Generalment es troben força tectonitzats, amb estructures gairebé verticals.

Un bon exemple d'aquesta estructura, el constitueix la denominada Roca de Pena. Es tracta d'un nivell vertical de gresos. (fotografies 11 i 12).

Aquesta estructura és tallada pel camí i pel riuet. En realitat es tracta d'un interessant "hock backs". 


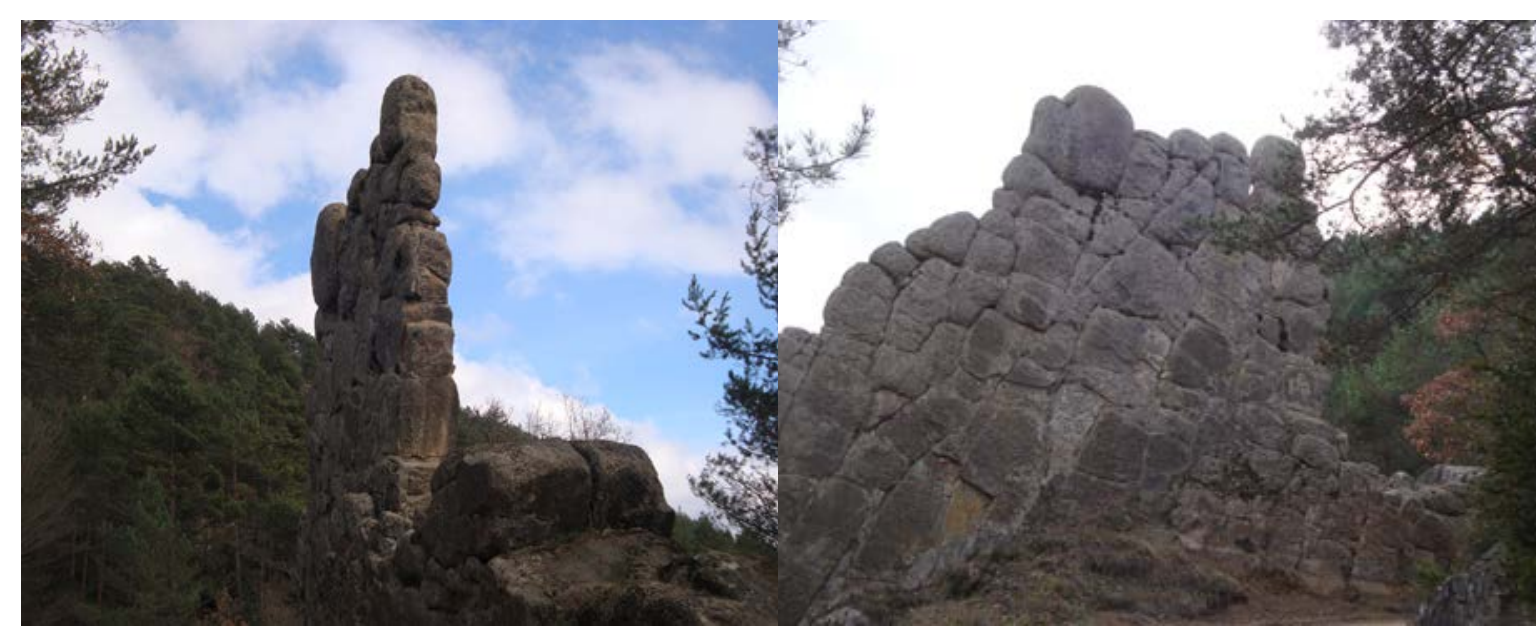

Fotografia 11. Visió lateral de la Roca de Pena

Fotografia 12. Visió frontal de la Roca de Pena

\subsection{Parada 12. Carretera a Borredà (BV-4654), immediacions del Km 16`3, (terme municipal d'Alpens, comarca d'Osona, subcomarca del Lluçanès). (Full 293).}

Després de realitzar l'aturada anterior, cal retornar a la carretera local BV - 4654, per tal de continuar cap el Nord, cap a Borredà. Així, poc a poc ens aproparem al límit comarcal. En arribar a les immediacions del Km 16’3 farem una nova aturada. Així, haurem recorregut uns 3 $\mathrm{Km}$ des de la parada anterior.

En aquest recorregut, hem trobat afloraments dels materials esmentats a l'aturada anterior. Així, inicialment (en tornar a la carretera) haurem vist afloraments de les calcolutites i gresos del Complex Al-luvial de Berga.

Més endavant, quasi a l'indret de la present aturada, haurem vist afloraments dels materials verticals que hem trobat a l'aturada anterior. Aquests son els materials que apareixen a l'indret de l'aturada. fotografia 13.

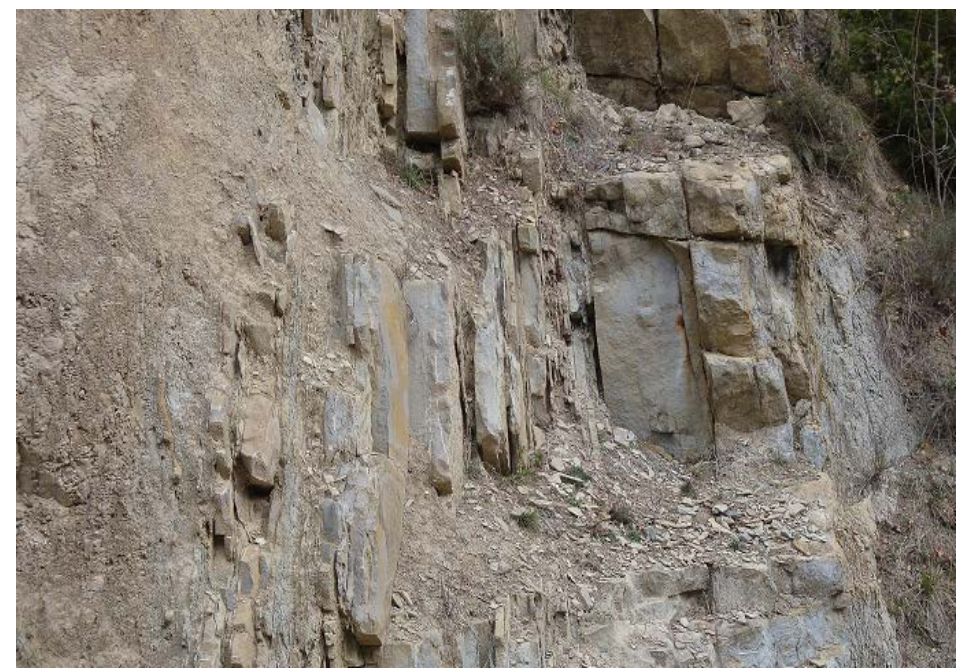

Fotografia 13. Un aspecte dels aflorament de les roques verticalitzades, 


\subsection{Parada 13- condicional. Carretera a Borredà (BV - 4654), Immediacions de L'Hostal Puigcercós, (terme municipal de Borredà, comarca del Berguedà). (Full 293).}

Després de realitzar l'aturada anterior, cal continuar cap a ponent per la carretera local BV 4654, per tal de continuar cap el Nord, cap a Borredà. Així, després de deixar enrere la comarca del Lluçanès (Osona), entrarem a la comarca del Berguedà, on estem ara situats, en aquesta aturada.

En aquest recorregut, hem trobat afloraments dels materials esmentats a l'aturada anterior. Així, trobarem per arreu afloraments de les calcolutites i gresos del Complex Al-luvial de Berga. Aquests són els que apareixen per aquest indret.

En aquest indret travessarem la Riera de Merlès, la qual es troba situada en bona part, dintre de la subcomarca del Lluçanès, repartint-se entre els sectors del Berguedà i els de la comarca d'Osona

En aquest indret finalitza el recorregut.

\section{Bibliografia}

COLLDEFORNS, B. (1986).- Estudi Geològic de la comarca del Bages. Públic. EUPM, 399 pàgines. Manresa.

GUIMERÀ, J. et altri (1992).- Geologia (II), Història Natural dels Països Catalans, Vol. 2, 547 pag. Enciclopèdia Catalana, S.A. Barcelona.

IGME (1975).- Mapa Geológico de España a Escala 1:50.000 (2a Sèrie). Full i Memòria no 363 (Manresa). Inst. Tecnológico y GeoMinero de España. Minist. Indus. Ener. Madrid.

MASACHS, V. et altri (1981).- Itineraris geològics per Anoia, Bages, Berguedà i Solsonès. Pub. Caixa d'Estalvis de Manresa, 205 pag. Manresa.

MATA-PERELLÓ, J.M. (1984).- Els Minerals del Bages i llurs jaciments. Revista Les Fonts, $n^{\circ}$ 2, pp. 1-32, Manresa.

MATA-PERELLÓ, J.M. (1991).- Els Minerals de Catalunya. Arxius de la Secció de Ciències, t. XCIII, Institut d'estudis Catalans. Barcelona.

MATA-PERELLÓ, J.M. (2013).- Recorregut de recerca geològica i mineralògica per les comarques del Berguedà, Osona (Lluçanès) i Bages: des de Gironella i la Quar a Lluçà, Prats de Lluçanès, Sant Feliu Sasserra, Avinyó i Artés. Inèdit. 15 pàgines. Manresa

MATA-PERELLÓ, J.M. et COLLDEFORNS, B. (1994).- Inventari Mineralògic de la comarca del Bages. Xaragall, $n^{\circ} 19,35$ pàgines. Manresa.

MATA-PERELLÓ, J.M. i SANZ BALAGUÉ, J. (1988).- Guia d’Identificació de Minerals (Països Catalans i d'altres). Edit. Parcir, 205 pag. Manresa.

RIBA ARDERIU, O. Et altri. (1976).- Geografia física dels Països Catalans. Edit Ketres. Barcelona. 